\title{
Malaria Prophylaxis and Immunosuppressant Therapy in Management of Nephrotic Syndrome Associated with Quartan Malaria
}

\author{
J. W. KIBUKAMUSOKE \\ From Makerere College Medical School, Kampala, Uganda
}

The evidence that is available for a possible immunological basis for the nephrotic syndrome associated with quartan malaria (Kibukamusoke, 1966; Kibukamusoke, Hutt, and Wilks, 1967; Soothill and Hendrickse, 1967) prompted a study of the possible value of removing the sensitizing agent (the malaria parasite). The use of antimalarials, however, has failed to produce any immediate therapeutic benefit so far (Gilles and Hendrickse, 1963; Kibukamusoke et al., 1967). However, the possibility still remains that prolonged malaria prophylaxis might be useful, and similarly immunosuppression in the treatment of this syndrome. The use of prednisone has been shown to be disappointing (Kibukamusoke, 1966; R. G. Hendrickse and J. F. Soothill, 1966, personal communication; Kibukamusoke et al., 1967). It was thought, therefore, that better results might be obtained if more effective immunosuppressants were used. The purpose of this paper is to report the results of studies into these two possibilities.

\section{Material and Methods}

Malaria suppression. The study of the value of malaria suppression in the treatment of this syndrome comprised 18 children, all of whom had initially received a course of prednisone in a dosage of $2 \mathrm{mg} . / \mathrm{kg}$. body weight for a period of 28 days without remission of proteinuria. These cases were then divided into two comparable groups of 9 cases each, and malaria prophylaxis was given to one group only. Both groups, however, continued with steroids for a similar time, i.e. 12-24 months (Table I). The dosage schedule used was the same as above, but medication was given only on the first 3 days of each week, and a maximum of $80 \mathrm{mg}$. prednisone a day was not exceeded in a single child.

Case matching was done on the basis of age, sex, and severity of glomerular histological change (Table I).

Received March 29, 1968.
Histological grading was similar to that used in a previous study (Kibukamusoke and Hutt, 1967).

Immunosuppression. In the immunosuppressant study 3 of the children in the above group were included in addition to 11 others. All these had received steroids for periods ranging from 2 months to 3 years without benefit. Renal histopathology was available in 11 of these cases. 10 children showed mild or minimal proliferative lesions and the other child had more severe proliferation of glomerular endothelial cells.

In none of the cases was a specific cause of the nephrotic syndrome found, nor was there evidence of streptococcal infection in the present or immediate past. 14 of the 18 children in the malaria suppression study originally had Plasmodium malariae in their blood, as did 12 of the 14 in the group to which immunosuppressants were given.

Malaria prophylaxis study. Full response was determined in terms of total abolition of proteinuria.

Malaria prophylaxis, varying from 12-18 months, was achieved by using Camoprima Infatabs*. These are available in tablet form each containing $75 \mathrm{mg}$. amodiaquine and $15 \mathrm{mg}$. primaquine. Two tablets were given to each child once on a particular day (Sunday) each week, this combination ensuring the elimination of both the tissue and blood forms of the malaria parasite (Adams and Maegraith, 1966).

Immunosuppressant study. Azathioprine was chosen because it is an effective immunosuppressant drug which rarely produces toxic effects if used with care (Rundles et al., 1961). It is a derivative of 6mercaptopurine and its side effects are predominantly on the bone-marrow where varying degrees of granulocytic depression may occur (Rundles et al., 1961; Dacie, 1962).

The dosage was $1.5-2.5 \mathrm{mg} . / \mathrm{kg}$. body weight, and this was given on every day of the week in a single dose in the morning until proteinuria disappeared, or for 12 months. The actual amount of drug given each day was found to be approximately $50 \mathrm{mg}$. (half a tablet) for each child.

\footnotetext{
$\star$ Parke, Davis, and Co., London.
} 
TABLE I

Effect of Malaria Prophylaxis on Steroid Resistance

\begin{tabular}{|c|c|c|c|c|c|}
\hline Case No. & Age (yr.) & Sex & Histology & $\begin{array}{l}\text { Plasmodium } \\
\text { Malaria }\end{array}$ & $\begin{array}{l}\text { Results After One Year's } \\
\text { Prophylaxis and Steroids }\end{array}$ \\
\hline \multicolumn{6}{|c|}{ Prophylaxis (protected) } \\
\hline 1 & 8 & $\mathbf{M}$ & Minimal prolif. glomerulonephritis & + & Responded $\star$ \\
\hline 2 & 9 & $\mathbf{M}$ & Mild prolif. glomerulonephritis & + & Responded \\
\hline 3 & 11 & $\mathbf{F}$ & Prolif. glomerulonephritis plus early tubular atrophy & - & Failed to respond \\
\hline 4 & 5 & $\mathbf{M}$ & Minimal focal prolif. glomerulonephritis & + & Responded \\
\hline 5 & 14 & $\mathbf{M}$ & Mild focal prolif. glomerulonephritis & + & Responded \\
\hline 6 & 14 & $\mathbf{F}$ & Mild prolif. glomerulonephritis & + & Responded \\
\hline 7 & 8 & $\mathbf{F}$ & Minimal prolif. glomerulonephritis & - & Failed to respond \\
\hline 8 & 14 & $\mathbf{M}$ & Mild prolif. glomerulonephritis & + & Failed to respond \\
\hline 9 & 7 & $\mathbf{M}$ & Mild prolif. glomerulonephritis & + & Responded \\
\hline \multicolumn{6}{|c|}{ No Prophylaxis (non-protecled) } \\
\hline 10 & 7 & $\mathbf{M}$ & Mild prolif. glomerulonephritis & + & Failed to respond \\
\hline 11 & 10 & $\mathbf{M}$ & Acute diffuse prolif. glomerulonephritis & - & Responded \\
\hline 12 & 5 & $\mathbf{F}$ & Minimal prolif. glomerulonephritis & + & Failed to respond \\
\hline 13 & 7 & $\mathbf{M}$ & Minimal prolif. glomerulonephritis & + & Responded \\
\hline 14 & 12 & $\mathbf{M}$ & Diffuse prolif. glomerulonephritis & + & Failed to respond \\
\hline 15 & 14 & $\mathbf{F}$ & Minimal prolif. glomerulonephritis & + & Failed to respond \\
\hline 16 & 7 & $\mathrm{~F}$ & Minimal prolif. glomerulonephritis & + & Responded \\
\hline 17 & 10 & $\mathbf{M}$ & Mild prolif. glomerulonephritis & - & Failed to respond \\
\hline 18 & 7 & $\mathbf{M}$ & Mild focal prolif. glomerulonephritis & + & Failed to respond \\
\hline
\end{tabular}

+ . Plasmodium malaria in blood; - plasmodium malaria not found.

* Responded indicates full response to therapy.

Total white cells and differentials were counted weekly during the first month of therapy and thereafter every 3 or 4 weeks. A decline in these counts was not observed in any child during the study. On the contrary, a mild leucocytosis of 10,000-13,000 white cells per cu.mm. was noted in $69 \%$ of the cases. This rise in white cell count often persisted for 2 or 3 weeks. Bone-marrow examination was, therefore, not performed.

\section{Results}

Malaria Prophylaxis Study (Table I). Of the 9 cases in the protected group, 6 obtained a complete remission of proteinuria, as compared with only 3 of the 9 in the non-protected group. Unfortunately it was impossible to study a larger group because of the high default rate and the length of time required to obtain a complete remission of proteinuria (12-24 months). The results, therefore, can be interpreted only as suggestive of benefit from malaria prophylaxis. In order to obviate this disadvantage, therefore, more convenient therapeutic regimens must be found.

Azathioprine study (Table II). Of the 14 children, 12 responded with a total disappearance of proteinuria, usually within 8 weeks, though some children required longer treatment. The reason for the lack of response in the other 2 children was obscure, but it was thought to be related to the lower original levels of malarial antibody titres which these 2 children had, compared with the rest of the group.

\section{Discussion}

Although a small percentage of cases of idiopathic childhood nephrosis seen in Europe and North America fails to respond to steroid therapy, this group of drugs has an established place in the management of the disease. The identification of an aetiological factor (the malaria parasite) in over $90 \%$ of nephrotic children in Nigeria suggested that the tropical nephrotic syndrome might be different from the type encountered in temperate climates (Gilles and Hendrickse, 1963). It soon became known that this was true in many tropical areas (Kibukamusoke et al., 1967).

Using the criterion of total abolition of proteinuria as indicating a full response to steroid therapy, it was found that only a small number of nephrotic children in East and West Africa responded. This feature is now recognized as distinctive for the form of nephrotic syndrome associated with quartan malaria (Kibukamusoke et al., 1967)

Owing to the relatively minor changes that are found in the glomeruli of these children, it was felt that response might be obtained with the use of some suitable drug. The finding of raised malaria antibodies in nephrotic sera (Kibukamusoke et al., 1967) and the persistence of malaria parasites in the circulation (despite this increase) raised the possibility of the damage being due to immunological reactions resulting from the deposition of immune complexes in the glomeruli. Evidence for these complexes has now been reported in the serum 
TABLE II

Azathioprine Therapy

\begin{tabular}{|c|c|c|c|c|}
\hline \multirow{2}{*}{ Case No. } & \multirow{2}{*}{ Glomerular Histology } & \multicolumn{2}{|c|}{ Steroid Therapy } & \multirow{2}{*}{$\begin{array}{c}\text { Results of Azathioprine } \\
\text { Therapy }\end{array}$} \\
\hline & & Duration (mth.) & Result & \\
\hline $\begin{array}{l}10^{\star} \\
19 \\
20 \\
5^{\star} \\
14^{\star} \\
21 \\
22 \\
23 \\
24 \\
25 \\
26 \\
27 \\
28 \\
29\end{array}$ & $\begin{array}{l}\text { Mild proliferation } \\
\text { Minimum focal } \\
\text { Mild focal } \\
\text { Diffuse proliferation } \\
\text { Mild proliferation } \\
\text { Minimum focal } \\
\text { Minimum focal } \\
\text { Focal proliferation } \\
\text { Mild proliferation } \\
\text { Focal proliferation } \\
\text { Mild proliferation }\end{array}$ & $\begin{array}{r}8 \\
5 \\
5 \\
24 \\
24 \\
6 \\
12 \\
12 \\
2 \\
2 \\
1 \\
12 \\
24 \\
36\end{array}$ & $\begin{array}{l}\text { Nil } \\
\text { Nil } \\
\text { Nil } \\
\text { Nil } \\
\text { Nil } \\
\text { Nil } \\
\text { Nil } \\
\text { Nil } \\
\text { Nil } \\
\text { Nil } \\
\text { Nil } \\
\text { Nil } \\
\text { Nil } \\
\text { Nil }\end{array}$ & 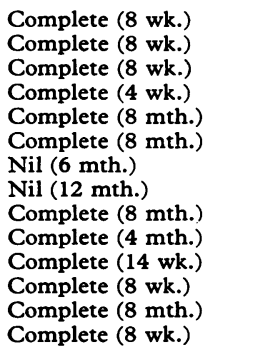 \\
\hline
\end{tabular}

$\star$ Cases which were also included in the original malaria prophylaxis study.

Complete $=$ total abolition of proteinuria.

The duration before response to azathioprine is given in brackets.

(Soothill and Hendrickse, 1967). Complementfixing antibodies have also been demonstrated by immunofluorescence (J. W. Kibukamusoke and P. A. Ward, 1968, unpublished data). It seemed logical, therefore, to study the effect of prolonged malaria suppression on the affected children. Though the study presented here was limited in terms of numbers, the results appear to suggest that this procedure might be beneficial. The drawback is the length of time required for treatment. An alternative regimen therefore seemed desirable.

The results obtained with the use of azathioprine seem to be encouraging, particularly as these children had earlier shown resistance to steroids. The total absence of toxic effects from the drug is also encouraging.

\section{Summary}

The possible value of prolonged malaria suppression in the management of the nephrotic syndrome associated with quartan malaria is reported. The results suggest that this procedure may be of value in bringing about a response to steroid drugs.
Azathioprine, an immunosuppressant drug, appears to be effective in a large percentage of patients suffering from this syndrome.

The studies were supported by the World Health Organization, and the U.S. Army Medical Research and Development Command grant No. DA-MD-49-193-636101.

\section{REFERENCES}

Adams, A. R. D., and Maegraith, B. G. (1966). Malaria prophylaxis and suppression. In Clinical Tropical Diseases, 4th. ed., pp. 246-250. Blackwell, Oxford.

Dacie, J. V. (1962). The Haemolytic Anaemias, Part II, 2nd ed., p. 678 . J. and A. Churchill, London.

Gilles, H. M., and Hendrickse, R. G. (1963). Nephrosis in Nigerian children. Role of plasmodium malariae, and effect of antimalarial treatment. Brit. med.f., $2,27$.

Kibukamusoke, J. W. (1966). The nephrotic syndrome in Lagos, Nigeria. W. Afr. med.f., 15, 213.

- and Hutt, M. S. R. (1967). Histological features of the nephrotic syndrome associated with quartan malaria. $f$. clin. Path., 20, 117.

- W and We N. E. (1967). The netic syndrome in Uganda and its association with quartan malaria. Quart. $\mathcal{F}$. Med., 36, 393.

Rundles, R. W., Laszlo, J., Hoga, T., Hobson, J. B., and Garrison, F. E., Jr. (1961). Clinical and hematologic study of 6 [(1-methyl-4-nitro-5-imidazolyl)thio]-purine [B. W. 57-322] and related compounds. Cancer Chemother. Rep., 14, 99.

Soothill, J. F., and Hendrickse, R. G. (1967). Some immunological studies of the nephrotic syndrome of Nigerian children. Lancet, 2, 629. 